\title{
Article
}

\section{Performance of a ventilated-façade system under fire conditions: An experimental investigation}

Eleni, Asimakopoulou, Dlonysios, Kolaitis and Maria, Founti Available at http://clok.uclan.ac.uk/33600/

Eleni, Asimakopoulou ORCID: 0000-0001-5644-1372, Dlonysios, Kolaitis and Maria, Founti (2020) Performance of a ventilated-façade system under fire conditions: An experimental investigation. Fire and Materials, 44 (6). pp. $776-$ 792. ISSN 0308-0501

It is advisable to refer to the publisher's version if you intend to cite from the work. http://dx.doi.org/10.1002/fam.2863

For more information about UCLan's research in this area go to http://www.uclan.ac.uk/researchgroups/ and search for <name of research Group>.

For information about Research generally at UCLan please go to http://www.uclan.ac.uk/research/

All outputs in CLoK are protected by Intellectual Property Rights law, including Copyright law. Copyright, IPR and Moral Rights for the works on this site are retained by the individual authors and/or other copyright owners. Terms and conditions for use of this material are defined in the policies page.

\section{CLoK}

Central Lancashire online Knowledge www.clok.uclan.ac.uk

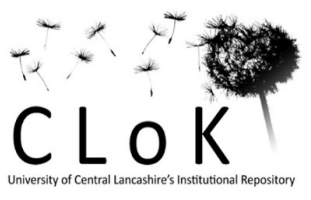




\title{
Performance of a ventilated-façade system under fire conditions: An experimental investigation
}

\begin{abstract}
During a fire event, ventilated facade systems may contribute to external fire spreading to the upper floors of a building via the facade, thus representing a significant risk. In this frame, the performance of a typical ventilated façade system under fire conditions is experimentally investigated, using a full-scale compartment-facade test rig. Two alternative façade configurations are examined and comparatively assessed, namely a plain façade (PF) and a ventilated façade (VF) system. Emphasis is given on the estimation of the thermal characteristics of the developed Externally Venting Flames (EVF) and the thermal boundary conditions developing on the façade's exposed surface. An extensive set of sensors was installed at the interior of the fire compartment, the façade systems and the exterior of the test configurations. Analysis of the experimental data suggests that even though gaseous combustion products managed to penetrate the air cavity of the VF system, no consistent flaming conditions were established. On the unexposed face of both PF and VF systems, temperatures remained constantly below $180^{\circ} \mathrm{C}$ throughout the duration of both fire tests. The Eurocode correlations are assessed against the obtained experimental data; certain parameters, such as EVF length, width and centreline temperature, are found to be under-estimated by the Eurocode methodology.
\end{abstract}

KEYWORDS: façade fire, large-scale fire test, ventilated façade, externally venting flame 


\section{INTRODUCTION}

\subsection{Ventilated Façade System}

Primary energy use in buildings, accounts for approximately $40 \%$ of the total annual energy consumption and $\mathrm{CO}_{2}$ emissions in the European Union [1]. Evidently, reducing energy consumption in the building sector is essential in order to meet a range of challenges related to national energy performance requirements, environmental protection and cost reduction. The use of innovative construction techniques and materials can serve as a means towards improving energy efficiency and thus achieving significant energy savings in buildings. One such novel construction technique is the Ventilated Façade (VF) system, which is essentially a double-wall construction, comprising an external lightweight cladding panel assembly and the "main" façade of the building (outdoors side of the external wall); these two layers are separated by an air cavity, where an additional thermal insulation material may be installed. VF systems are increasingly used in contemporary architecture, both in new constructions and in retrofitting projects of existing buildings.

VF systems were initially used to protect buildings against rain and wind, aiming to enhance the durability of the building's façade [2]; however, due to the ever stricter building energy requirements, modern VF systems are further employed to reduce building energy consumption, by means of additional thermal insulation and protection against solar radiation $[3,4,5]$. As a result, there is an ever-increasing installation of VF systems in regions with higher levels of solar radiation $[6,7]$. The VF system's good energy performance is owed to the existence of the air cavity between the building's wall (inner skin and insulation) and the external cladding (outer skin) [2]. The outer skin is usually composed of modular panels, with integrated metallic, ceramic, stone or composite tiles [2]. Heating of the external cladding panel by the incident solar radiation results in increasing temperatures in the air cavity; the heated air flows upwards, due to thermal buoyancy (natural convection). Ambient air can enter and exit the cavity through ventilation openings, located at its lower and upper side, respectively. Air movement through the cavity, due to the "chimney effect", offers several benefits in terms of the façade's hydrothermal behaviour, e.g. it contributes in limiting the emergence of moisture due to rain or condensation. The width of the air cavity may vary depending on the substructure ranging from $0.02 \mathrm{~m}$ [8] to even $0.2 \mathrm{~m}$ [9]. The inner skin is the main element that provides the thermal resistance to the building's external walls. It is commonly built using high (e.g. bricks, concrete etc.) or low density (e.g. sandwich panels, gypsum plasterboards etc.) materials; an additional external layer of thermal insulation may be installed in the air cavity [2]. 
Specifications regarding the design and the materials used in the inner and outer skin, the air cavity and the thermal insulation may vary substantially, based on the national construction and fire protection standards and regulations that are in effect in each country. These varying configurations have led to a series of issues regarding their hydrothermal, energy, sound and fire performance [10]. Construction details (e.g. cladding fixings) [8] or fire barriers [11, 12] may also affect flame spreading within the ventilation air cavity.

\subsection{Fire Risks Associated with Ventilated Façades}

During a fire event, a VF system may contribute to external fire spreading to the upper floors of a building, especially when Externally Venting Flames (EVF) are established. In this case, the "chimney effect" poses a severe threat [9], since the air cavity may serve as a pathway for the fire and hot combustion products to spread beyond the compartment of the fire origin (Figure 1, right). Once the fire enters the air cavity, the potential increase in the fire spreading rate depends on the existence and the nature of the thermal insulation materials in the cavity, the construction details of the façade and the geometric characteristics of the cavity $[9,13]$. Typically, during a compartment fire event, window and door frames may provide a direct entry route to the air cavity. In such a case, flames may enter the cavity and, if appropriate fire barriers or seals have not been installed, they may propagate upwards. Several recent incidents around the word $[14,15]$ indicate that fire and smoke spreading through cavities may be more rapid than fire spreading through the outer cladding façade. This type of scenario may result to rapid upwards fire spreading with temperatures exceeding $600^{\circ} \mathrm{C}[13]$ posing a serious threat to the strength and integrity of both the façade system and the building itself. Evidently, preventing fire spreading in the air cavity is crucial; towards this end, a number of fire protection regulations require the installation of fire barriers. The fire barriers that are commercially available make extensive use of intumescent materials, which allow air movement under normal operation, whereas they "seal" the cavity in the event of fire. However, the lack of proper fire barrier installation procedures may result in failure of properly blocking the cavity flow, a fact evidenced also in the recent Grenfell Tower fire [16].

Due to the increasing number of fire events in high-rise buildings [17, 15] and the ever-stricter requirements for building thermal insulation, the fire safety characteristics of external façade systems has become an important issue [18]. Although several authors have highlighted the effect of the façade's geometric characteristics on the externally venting flame development and propagation $[17,19,20]$, literature reports on VF systems focus mainly on investigating their behaviour in terms of energy consumption reduction $[2,3,6]$; only recently there has been 
an effort to document the respective fire safety regulatory requirements and specification of use across Europe [10]. In this context, a façade fire performance assessment approach highlighted the need for further research on façade fire tests [21]; the identified priority research issues are related to the effect of environmental factors, fuel type, measuring equipment, heat exposure, external fire scenarios, façade components and building techniques.

Limited reports can be found in the literature addressing the fire behaviour and hazards associated with façade air cavities, e.g. double skin facades [22, 23, 24], VF systems [13, 25, 26] and their construction details, e.g. cladding fixings and geometric characteristics of ventilation cavities $[8,9]$. A series of full-scale SP Fire 105 standard tests on fully ventilated cavities behind plywood cladding were recently performed to study the flame spread characteristics in combustible façade claddings with and without a ventilation cavity $(0.02 \mathrm{~m}$ width, no fire barriers) [9]. In the large-scale fire tests, the additional heat release due to the combustible cladding was found to increase with increasing width of the air cavity, since when a wider air cavity was used, the combustible plywood could burn from both sides. Burning of the unexposed surface was both visually observed, after the end of each test, and measured with surface and air temperature measurements.

A more detailed study, focusing on the influence of the cavity width, ranging from $0.02 \mathrm{~m}$ to $0.1 \mathrm{~m}$, on the flame height and the incident heat flux to the inner surface of the cavity, has recently been published [8]. A full-scale experimental setup, comprising two parallel facing non-combustible plates and a propane burner was used to emulate a configuration of ejected flames next to a wall or from a burning cladding. Incident heat fluxes at the interior sides of the facing walls were shown to increase with the decrease of the air cavity width.

Recently, the fire plume behaviour and the prevailing conditions for the plume attachment to either the interior or the exterior wall of a double-skin façade has been investigated experimentally and numerically, using a medium-scale compartment-façade setup [24]. Nine different configurations were experimentally investigated, by varying the air cavity width and the fire power. In addition, a numerical simulation tool was validated using the obtained experimental results and a parametric study was performed by simulating 445 different configurations. It was found that the plume trajectory depends on both the heat release rate (HRR) and the width of the air cavity. A new criterion to predict whether the fire plume would attach to the interior or exterior wall skin was proposed, depending on the HRR, opening geometry and air cavity width values. 
In this context, the main scope of this work is to investigate the underlying phenomena affecting the fire behaviour characteristics of a typical VF system, by comparatively assessing the results obtained in two full-scale compartment-façade fire tests.

\section{EXPERIMENTAL SET UP}

\subsection{Test Compartment Configuration and Ambient Conditions}

Two full-scale fire tests were performed at the premises of Greek Firefighting Academy located in Athens, Greece, aiming to investigate the fire behaviour of the VF system. The first test, aimed to be used as a benchmark case, was performed using a conventional (non-ventilated) Plain Façade (PF); in the second test, a typical Ventilated Façade (VF) system was employed. Both tests were performed at the same large-scale compartment-façade experimental test rig; a schematic drawing of the test rig is presented in Figure 2. According to the recorded meteorological data, the ambient conditions prevailing during the $\mathrm{VF}$ fire test were $21.3^{\circ} \mathrm{C}$ average temperature, $62 \%$ relative humidity and $3.1 \mathrm{~km} / \mathrm{hr}$ average wind speed at a NorthNortheast direction. The day that the PF fire test took place was less windy, with recorded ambient conditions $19.5^{\circ} \mathrm{C}$ average ambient temperature, $68 \%$ relative humidity and $2.4 \mathrm{~km} / \mathrm{hr}$ average wind speed at an East direction. At the start of VF and PF fire tests, the average fire compartment interior temperature was recorded to be $25.3^{\circ} \mathrm{C}$ and $26.6^{\circ} \mathrm{C}$, respectively.

The internal dimensions of the test compartment measured $1760 \mathrm{~mm}$ (width) x $800 \mathrm{~mm}$ (depth) x $2100 \mathrm{~mm}$ (height); it was lined with a double layer of standard $12.5 \mathrm{~mm}$ fire-resistant gypsum plasterboards. The compartment had a single window-type opening, measuring $765 \mathrm{~mm}$ x 1100 $\mathrm{mm}$. The window was located on the South side; the distance of the windowsill from the compartment's floor was $940 \mathrm{~mm}$. The external façade wall, attached to the South side of the compartment, measured $2614 \mathrm{~mm} \times 5230 \mathrm{~mm}$ (Figure 3, a); timber studs and battens on top of the compartment were used to support the back side of the façade (Figure 3, b).

In Figure 1, a schematic drawing of the different facade assemblies used in each test is given. In the case of the PF test (Figure 1, left), the external facade comprised a standard $12.5 \mathrm{~mm}$ thick cement board, covered externally by a $5 \mathrm{~mm}$ thick plaster coating layer. In the case of the VF test (Figure 1, right), the backing of the façade (inner skin) was formed by employing a commercial $15 \mathrm{~mm}$ thick gypsum plasterboard, upon which perforated metal steel studs were installed horizontally, at a vertical distance of $600 \mathrm{~mm}$, to support the external cladding panels. 
The outer skin of the façade was identical to the PF test, comprising a standard $12.5 \mathrm{~mm}$ cement board and a $5 \mathrm{~mm}$ plaster coating layer. The width of the air cavity formed between the inner and the outer skin was $25 \mathrm{~mm}$. The perforated metal studs may considered to be a rudimentary form of fire barrier; no additional (e.g. intumescent) fire barriers were installed, in order to allow investigation of the flow and thermal characteristics of a rather "unobstructed" gas flow movement at the interior of the air cavity, thus representing a worst-case scenario. In the VF case, an opening on the upper side of the window frame (lintel) supplied ambient air to the air cavity (Figure 3, c, d); the other 3 sides of the window frame were closed. The air cavity was also open at the bottom and top edges of the VF system, located $5230 \mathrm{~mm}$ apart.

A stainless-steel rectangular pan, measuring $700 \mathrm{~mm} \times 700 \mathrm{~mm} \times 250 \mathrm{~mm}$, was installed at the centre of the compartment floor, holding the $56.7 \mathrm{~kg}$ of $\mathrm{n}$-hexane used as the fire load; the bottom side of the pan was located $100 \mathrm{~mm}$ above the floor (Figure 4). The lower heating value of the n-hexane used in the tests was estimated, using an oxygen bomb calorimeter [27], to be $43521.17 \mathrm{~kJ} / \mathrm{kg}$. This "expendable" fuel source was employed to better simulate the dynamic nature of a real building fire. The fire load and opening dimensions were carefully selected in order to establish strongly under-ventilated fire conditions, thus ensuring the development of an EVF. The peak fire power achieved, estimated using the instantaneous mass loss rate measurements, was 4.5 MW; the total duration of both fire tests was approximately $880 \mathrm{~s}$.

\subsection{Sensors and Data Acquisition System}

An extensive set of sensors was installed both inside and outside the test compartment, aiming to record the temporal variation of several important physical parameters, such as gas and wall surface temperatures, gas velocities, incident heat flux, fuel mass loss rate and flame envelope geometry. The obtained measurements provided a detailed physical description of the main characteristics of the turbulent, reactive and multi-component flow-field developing inside and outside the test compartment. Emphasis was given to the characterization of the thermal environment developing near the façade wall, along the height of the EVF plume. Towards this end, $30 \mathrm{~K}$-type thermocouples, $1.5 \mathrm{~mm}$ in diameter, were used to measure gas temperatures in the vicinity of the fire plume; 34 additional K-type thermocouples were installed at seven specific heights along the façade, namely 0, 500, 750, 1000, 1500, 2000 and $2500 \mathrm{~mm}$ above the window lintel, aiming to record wall surface temperatures. Wall temperatures at the exposed and unexposed sides of the PF and VF systems were recorded, as well as gas temperatures inside the cavity of the VF system. Three water cooled, $25 \mathrm{~mm}$ diameter, 
Schmidt-Boelter total heat flux sensors were placed at the centreline of the PF system façade surface facing the EVF at $500 \mathrm{~mm}, 1000 \mathrm{~mm}$ and $2000 \mathrm{~mm}$ heights above the window lintel. Schmidt-Boelter type heat flux sensors are aimed to be used in thermal environments mainly dominated by radiative heat flux.

In Figure 4, a general schematic depicting the locations of the measurement equipment during the VF fire test, is depicted. The origin of the coordinate system is assumed to be located at a point that lies at the mid-point $(y=0)$ of the external face of the façade, at the height of the window lintel. The five measurement locations across the VF system "depth" are labelled as follows: positions 1 and 2 correspond to the unexposed and exposed surface of the internal gypsum plasterboard (inner skin), position 3 records gas temperatures at the middle-span of the air cavity and positions 4 and 5 correspond to the unexposed and exposed surface of the external panel (outer skin), consisting of the cement board and the plaster coating (Figure 1, right). In the PF system, façade temperatures only at positions 4 and 5, corresponding to the unexposed and exposed surface of the external board, were recorded (Figure 1, left).

Although the focus of this work was the determination of the EVF characteristics, the thermal field developing inside the compartment was also investigated. Towards this end, 5 K-type thermocouples, located at different heights above the centre of the compartment floor (and the pool) were used to monitor the temperature profile established at the interior of the fire compartment. The recorded thermocouple data, obtained at the interior of the compartment, were corrected for radiation using a "post-processing" methodology [28]. All thermocouple measurements were recorded using a Universal Data Logging Interface designed in the LabView software; the sampling period was $1 \mathrm{~s}$. The fuel mass was continuously monitored using a load cell, exhibiting a $2 \mathrm{mV} / \mathrm{V}$ sensitivity at a capacity of $500 \mathrm{~kg}$, installed under the fuel pan.

In addition, velocity measurements of the gases entering and exiting the fire compartment through the window opening were recorded using a vertical array of four bi-directional velocity probes, placed at various heights $(220,440,660$ and $880 \mathrm{~mm}$ below the window lintel) along the centreline of the window; these were supplemented by thermocouples, located at the same positions (Figure 4), to allow for temperature compensation of the measured velocity values. Variations in flame shape and position were recorded using two optical video cameras, one positioned directly opposite from the façade's exposed surface, at a distance of $8600 \mathrm{~mm}$, and the other at a right angle to the facade, at a distance of $9400 \mathrm{~mm}$. A thermal camera was also 
positioned opposite to the façade, at a distance of $8600 \mathrm{~mm}$, to record additional information regarding the thermal response of the façade surface during each test.

\subsection{Experimental Uncertainty}

The ASME methodology was used to estimate the experimental uncertainty, as recommended in previous studies $[29,30]$. The systematic standard $\left(B_{i}\right)$ and total expanded $\left(U_{t}\right)$ uncertainty were calculated for all components; the respective estimated values are tabulated in Table 1. Estimation of the systematic standard uncertainty was based on relevant information regarding the thermocouples [29, 31], heat flux meters [32], bidirectional probes [33, 34] and the load cell [35] used in the tests.

\section{RESULTS AND DISCUSSION}

\subsection{Fuel Consumption Rate}

In small- or medium-scale fire tests performed in a well-controlled laboratory environment, where the exhaust gases are collected in a hood placed above the fire compartment, it is possible to estimate the HRR by means of oxygen calorimetry. However, this is not possible in largescale fire tests conducted outdoors; in this case, it as a common practice to estimate the HRR using Equation (1), where $\operatorname{MLR}(\mathrm{kg} / \mathrm{s})$ is the fuel mass loss rate and $H_{u}(\mathrm{~J} / \mathrm{kg})$ is the fuels' lower heating value.

$$
H R R=M L R \cdot H_{u}
$$

The HRR of a pool fire in a compartment is influenced by a variety of parameters such as ventilation, radiation from the surrounding walls and thermal characteristics of the exposed rim above the fuel $[36,37]$. Both PF and VF tests exhibited similar conditions at the interior of the

fire compartment and an almost constant fuel combustion rate was observed throughout both fire tests (Figure 5, left). The pool fire burned steadily until it entered the fire decay stage and the unburnt fuel volatiles exited the fire compartment resulting in the development of EVF due to the prevailing under-ventilated conditions. The duration of the fire growth period lasted approximately $60 \mathrm{sec}$ for both cases and the duration of the fully developed fire stage for the PF and VF cases was $800 \mathrm{~s}$ and $700 \mathrm{~s}$, respectively. The duration of the decay phases was 100 $\mathrm{s}$ for the PF and $150 \mathrm{~s}$ for the VF case. 
The total HRR is calculated by assuming unity combustion efficiency using Equation (1), raw MLR data are also provided in Figure 5. The derived MLR signal was rather noisy due to the increased turbulence at the interior of the fire compartment. In order to further calculate the HRR of the EVF a correlation to estimate the HRR at the interior of the fire compartment [37] that is widely used for rectangular compartment fires with one opening is used. The methodology was followed by using Equations (2) and (3) for each fire test. The respective interior and EVF HRR for both PF and VF fire tests are also presented in the right-hand side of Figure 5. The temporal evolution of the time-averaged, using an averaging period of $60 \mathrm{~s}$, values of fuel mass and HRR, for both cases, is depicted in Figure 5.

$$
\begin{aligned}
& Q_{\text {inside }}=1500 A(H)^{1 / 2} \\
& Q_{E V F}=Q_{\text {total }}-Q_{\text {inside }}
\end{aligned}
$$

\subsection{Compartment Gas Temperatures}

The gas temperature evolution inside the compartment, in both fire tests, is depicted in Figure 6. The three characteristic stages of fire growth, quasi steady-state (corresponding to fully developed fire conditions) and decay, typically encountered in compartment fires, can be easily identified in both test cases. In general, temperatures at all heights increase rapidly right after ignition. As expected, gas temperature values decrease with increasing height; the maximum recorded values at the interior of the compartment reached $1100^{\circ} \mathrm{C}$. However, due to the entrapment of the hot gas layer below the ceiling, temperatures measured $100 \mathrm{~mm}$ above the window lintel are generally higher than the respective values recorded $100 \mathrm{~mm}$ below the window lintel. It is evident that despite the fact that the two large-scale natural fire tests were performed outdoors on two different dates, therefore being exposed to different climatic conditions, the thermal field developing inside the fire compartment was quite similar in both cases, thus resulting in an acceptable level of "test repeatability", which allows the comparative assessment of the respective experimental results; the main difference among the two tests is only the onset of the decay phase, which is found to be delayed by approximately $90 \mathrm{~s}$ in the PF case. 


\subsection{Opening Flow Velocities}

Incoming ambient air enters the compartment through the lower part of the opening, whereas combustion product gases, unburnt fuel vapours and smoke exit through the upper part of the opening. The time evolution of the horizontal gas velocities at the centreline of the window, at four different heights, i.e. 220, 440, 660 and $880 \mathrm{~mm}$ below the window lintel, are depicted in Figure 7. The negative velocities recorded at the lower measuring levels (-660 $\mathrm{mm}$ and -880 $\mathrm{mm}$ ) imply ambient air flowing into the fire compartment. The recorded velocity values among the two test cases are qualitatively similar but exhibit modest quantitative differences. For instance, whereas the time-averaged incoming air velocities are roughly equal (of the order of $-1 \mathrm{~m} / \mathrm{s}$ ) in both cases, the time-averaged outflowing gas velocities range from $1.8 \mathrm{~m} / \mathrm{s}$ (PF case) to $3 \mathrm{~m} / \mathrm{s}$ (VF case). This difference is mainly owed to the particularly turbulent external wind conditions prevailing during the VF test, which affected considerably the swirling and tilting patterns of the developing EVF. Ambient air velocity measurements were conducted with an anemometer located near the fire compartment; the peak ambient air velocity reached $1.78 \mathrm{~m} / \mathrm{s}$ during the PF test, whereas the respective value was $3.50 \mathrm{~m} / \mathrm{s}$ during the VF test.

\subsection{EVF Shape and Dimensions}

An in-house developed flame detection image processing tool [38] has been employed for the analysis of the EVF geometry. The EVF envelope shape and dimensions were determined by calculating the time-averaged flame probability (intermittency). Figures 8 and 9 depict the spatial distribution of the flame intermittency for the PF and VF tests, as seen from the front and the side respectively; image artefacts on the left of the front side view are owed to the presence of the thermocouple trees positioned at the exterior of the experimental configuration. In both cases, the EVF are projected through the upper half of the opening, at an angle of approximately $45^{\circ}$ and then they bend upwards. Analysing the recorded video sequences, it was observed that, at specific instances, the EVF tended to curl back and impinge upon the façade wall above the opening, due to peripheral air entrainment and abrupt external wind gusts.

In both cases, a typical behaviour for an EVF shape developing in an under-ventilated compartment fire was observed [30]. Uncertainty in determining the EVF dimensions arises mainly from the different definitions of the mean or peak flame height $\left(L_{L}\right)$, width $\left(w_{f}\right)$ and total projection from the façade $\left(L_{p}\right)[37,39,40]$. 
Visual observations tend to yield slight overestimates of $L_{L}$, so image processing analysis is commonly used to provide more accurate results, using high frame per second analysis methodologies for the determination of flame intermittency; the latter quantity is essentially the fraction of time that the flame appears in the respective point [37]. Since the flame is highly fluctuating, due to the developing intense turbulent field, the EVF dimensions are usually determined by calculating the average flame probability (intermittency). Early research [39] indicated that the fire plume above a fuel source can be divided into three main regions, characterised by the average flame probability. Using flame intermittency criteria, these three distinct regions, namely the "continuous flame", the "intermittent flame" and the "far-field plume", can be also identified in EVF [41, 42]. In this context, the flame height corresponding to the "continuous flame" ( $L_{L, 0.95}, 95 \%$ intermittency), "average flame" $\left(L_{L, 0.50}, 50 \%\right.$ intermittency) and "intermittent plume" ( $L_{L, 0.05}, 5 \%$ intermittency) regions can be obtained; beyond the latter region the flame cannot be seen and only hot combustion products are present (fire plume), Figures 8 and 9. The total flame height $\left(L_{L}\right)$ can be estimated using either the $50 \%$ flame intermittency limit $\left(L_{L, 0.50}\right)$, or, alternatively, by averaging the estimated flame height at the "continuous flame" $\left(L_{L, 0.05}\right)$ and "intermittent plume" $\left(L_{L, 0.95}\right)$ regions [40]; values obtained using both methodologies are in very good agreement [30].

Figure 10 illustrates the methodology used to estimate the "average flame" region height, $L_{f, 0.50}$. In this context, the flame height corresponding to $L_{f, 0.95}, L_{f, 0.50}$ and $L_{f_{-} 0.05}$, regions were obtained. The variation of the time-averaged (over the entire test) flame intermittency values with height, at the centreline of the flame, is depicted in Figure 10; above the average flame region, the flame intermittency decreases monotonically with height. The mean flame height is assumed to be equal to the largest height value where $50 \%$ flame intermittency is observed; in Figure 10 , this point is marked with an asterisk. In agreement with recent literature reports [43, 44], it was observed that the EVF average height in the VF fire test decreased with the observed increase of external wind velocity (c.f. Section 2.1). This decrease is partially attributed to the increase in air entrainment from the front direction.

The EVF width $\left(w_{f}\right)$, projection $\left(L_{H}\right)$ and total projection $\left(L_{p}\right)$ were estimated using the timeaveraged flame intermittency values. Unlike to the methodology used to determine the EVF height, it is not a straightforward procedure to define the mean values of $w_{f}$ and $L_{H}$, since the flame intermittency is not monotonically decreasing. The EVF width is estimated as the maximum difference between the maximum and minimum value of width across all flame heights, marked with two asterisks in Figure 11. Figure 12 depicts schematically the variation 
of flame intermittency as a function of the horizontal distance from the façade. Flame projection was assumed to be equal to the largest distance from the façade where $50 \%$ flame intermittency is observed (marked with an asterisk). A summary of the estimated values for the EVF height, width $\left(w_{f}\right)$, projection $\left(L_{H}\right)$ and total projection $\left(L_{p}\right)$ is presented in Table 3 for both test cases. The EVF reached higher heights and projected further from the façade during the PF fire test. Differences in EVF dimensions during PF and VF tests are mainly attributed to the different climatic conditions prevailing in each fire test, thus suggesting that the performance of PF and VF configurations, using inert materials, is quite similar. However, since there are indications in the recent literature [9] that the existence of the air cavity in the VF system may have an impact on the fire development, additional parameters to evaluate the behaviour of the different façade construction techniques are examined and presented in the following Sections 3.5 and 3.6.

\subsection{EVF Temperatures}

Time-averaged (during the fully developed fire period) outdoor gas temperature contour plots for each test case are shown in Figure 13, PF (left) and VF (right) tests. These contour plots are used to determine the spatial distribution of the EVF-induced thermal field developing outside the fire compartment. The depicted data were obtained by linear interpolation of the temperature measurements at the exterior of the fire compartment. The calculated far EVF edge limit $\left(L_{H}+h_{e q} / 3\right)$, according to Eurocode 1, Part 1-2, Annex B [45], are depicted in the form of dashed black lines in Figure 13.

In the PF test, maximum temperature values up to $900^{\circ} \mathrm{C}$ were observed at the vicinity of the opening. During the VF test, the EVF was established closer to the façade wall, a fact that is mainly attributed to the different meteorological conditions prevailing in each test day. The gas temperature decreases with increasing height in both test cases but there seems to be a considerable deviation of the EVF temperature profiles. During the PF test, a larger EVF is formed that is not attached to the façade. This is not the case in the VF test case, where a less intense EVF fire plume is formed, which is almost constantly attached to the façade's external wall; the observed differences are mainly owed to the effect of the different external wind conditions (c.f. Section 2.1). The different façade construction technique may also be a factor, but further research in a more controlled environment should be conducted on ventilated façade systems with small air width cavity to fully support this statement. 


\subsection{Façade Temperatures and Heat Flux}

The developing EVF imposes both a radiative and a convective heat flux on the external surface of the façade. The intense heat transfer to the façade results in increased exposed surface temperatures that were measured to be up to $500^{\circ} \mathrm{C}$; in Figure 14 (middle), an infrared image of the exposed façade surface just after flameout of the VF test is depicted. Visual observation (Figure 14, left) after the end of VF test, when the outer skin of the VF system was removed, suggested penetration of combustion products into the air cavity; only a slight deformation of the perforated steel stud of the VF system, just above the window lintel, could be observed (Figure 14, left).

The temporal evolution of the wall surface $(1,2,4,5)$ and gas (3) temperatures measured across the various layers of both façade systems (c.f. Figure 4) is depicted in Figure 15. Wall temperatures at the unexposed side of both PF and VF systems increased slowly during the first $200 \mathrm{~s}$ and remained constant throughout the duration of the test. The highest temperature values were observed close to the opening lintel $(z=500 \mathrm{~mm})$. Thermocouples installed at position 3 (c.f. Figure 4) were used to measure the gas temperatures at the middle of the VF system's air cavity. It can be observed that hot gases indeed entered the air cavity through the perforated steel stud above the opening lintel (c.f. Figure 14, left). In fact, the sudden increase in the air cavity temperature measurements at a height of $500 \mathrm{~mm}$, coincided with the emergence of the EVF. However, as the EVF progressively evolves at the exterior of the compartment and due to the consistently high horizontal exit velocities (c.f. Figure 7), the bulk of the exiting hot gases are dispersed outdoors, forming the EVF, and only a very small percentage enters the air cavity through the window lintel. Gas temperatures inside the cavity are gradually increasing; at the lowest measuring position $(z=500 \mathrm{~mm})$ they reach $280^{\circ} \mathrm{C}$ shortly after the end of the fully developed fire stage, but due to heat losses along their upwards path, they are gradually cooled with increasing height. It is evident that even though combustion products and unburnt fuel vapours may manage to enter the air cavity, no consistent flaming is observed; the perforated steel stud installed at the window lintel may have assisted in preventing flame spreading inside the cavity. The reported air cavity temperature measurements, supported by visual observations during and after the fire test, suggest that in the absence of a combustible insulation material installed in the air cavity, flame spreading along the vertical direction is not enhanced by the VF system. Overall, both PF and VF systems using inert materials seem to exhibit a very similar thermal performance, a claim supported by the recorded temperature values inside the air cavity and on the unexposed façade surface. 
The temporal evolution of the measured and calculated heat flux values at the exposed surface of the PF system are illustrated in Figure 16. During the growth phase of the fire, heat flux values gradually increase and as time passes by, EVF consistently covers the region above the opening, resulting in higher incident heat flux on the façade surface. Heat flux measurements are presented until $600 \mathrm{~s}$, after which there was an equipment failure. Recent fire events in high-rise buildings [26] indicate that the total heat flux induced by the EVF can be severe and may lead to fire propagation to adjacent floors or buildings. Maximum heat flux values 500 $\mathrm{mm}$ above the window lintel, at position HF1, reached $250 \mathrm{~kW} / \mathrm{m}^{2}$ but not for more than a few seconds at a time. The EVF itself acts as a radiation source; in addition, as it evolves towards the exposed surface of the façade it imposes a convective heat flux. The facade absorbs heat from the plume and restricts the air entering through the wall side. At a height of $2000 \mathrm{~mm}$ from the opening lintel, at position HF3, heat flux exposure was decreased with maximum instantaneous peak values reaching $150 \mathrm{~kW} / \mathrm{m}^{2}$.

\section{FIRE PERFORMANCE AGAINST STANDARDS}

\subsection{Large-Scale Standard Façade Fire Tests}

In several countries, current legislative requirements suggest that if the façade of a building comprises a wall with different elements, the wall system must be fire resistant and it should be tested according to the standards that apply to curtain walls or walls (e.g. EN 1364 [46]). Sometimes, the façade system must also be tested to assess its reaction to fire behaviour (e.g. EN 13501-1 [47]). In addition to that, numerous fire testing methods have been developed worldwide, at medium- and large-scale level, to classify the fire behaviour of façade systems. The majority of the available large-scale façade fire tests replicate real fire scenarios where EVF exit through an opening of the compartment, essentially simulating either post-flashover conditions or fully-developed ventilation-controlled conditions.

There are two international standard methods, ISO 13785-1 and ISO 13785-2, where intermediate- [48] and large-scale [49] fire tests, respectively, are employed to assess nonloadbearing facades and claddings. In Germany, the DIN E 4102-20 [50] and in the U.S.A., the NFPA 285 [51] tests are used to assess facade claddings or complete external wall systems. In the U.K., BS 8414-1 [52] is used for non-loadbearing external cladding systems and BS 84142 [53] for non-loadbearing external systems fixed and supported by a structural steel frame. Non-loadbearing facade systems mounted in a lightweight concrete wall and representative of the end use are evaluated using the SP FIRE 105 test in Sweden [54]. Due to the large 
differences exhibited among the various national façade fire test standards in Europe, there is currently an effort to develop a new European homogenized façade fire testing standard [18, 21]. The main characteristics of the major façade fire test standards used worldwide are presented in Table 2; the respective characteristics of the fire tests presented in this work are given in comparison. As it is pointed out in Table 2, the set up and failing criteria of the most commonly used standardized facade test methods are quite diverse, although some similarities can be identified between certain testing protocols (e.g. existence or not of lateral wall, fire exposure and failure due to external fire spread etc.). It is evident that, even though the performed PF and VF tests have not followed any specific facade fire test standard, the main operational parameter values (e.g. experimental apparatus dimensions, peak HRR, heat flux exposure levels on the façade) were similar to the respective values proposed in the standard tests. Additional measurement equipment, as opposed to standard testing practice, has been used to monitor the PV and VF system performance and the characteristics of the developing EVF. In this context, the performance of the investigated façade systems is further assessed, by using the relevant pass/fail criteria of the previously mentioned standard façade fire tests. More specifically, a façade system is considered to exhibit an acceptable fire behaviour, when the temperature on its exposed surface (outer skin) does not exceed $450^{\circ} \mathrm{C}$ [54], 500 ${ }^{\circ} \mathrm{C}$ [50], $538^{\circ} \mathrm{C}$ [51] or $600^{\circ} \mathrm{C}$ [52], at various heights. In addition, another criterion focuses on the temperature of the unexposed surface, which should not exceed $278^{\circ} \mathrm{C}$ above the ambient temperature [51]; a similar criterion is cited in Australian Standard AS1530.4, where a structural element (e.g. wall, floor) is considered to fail when the maximum temperature rise (above the ambient temperature) of the ambient facing side (unexposed side) exceeds $180^{\circ} \mathrm{C}$ [55].

By employing the aforementioned criteria, the investigated PF and VF systems are considered to perform satisfactorily, during the $900 \mathrm{~s}$ fire exposure. By taking into account all temperature measurements taken across the façade system assemblies (Figure 15), it is observed that the exposed façade surface did not exceed $450^{\circ} \mathrm{C}$ for more than $2 \mathrm{~min}$; in addition, no temperatures above $180^{\circ} \mathrm{C}$ were recorded on the unexposed face. Furthermore, gypsum plasterboards exposed to fire are considered to exhibit mechanical failure when cracks or openings are observed through the wall [56]; after the VF fire test, no visual observation of cracks on the gypsum plasterboards was made. The thermal field developing due to the emergence of the EVF imposes a severe thermal loading on the exposed façade surface (c.f. Figure 16). However, due to the multi-layered construction of the VF system, temperatures at both faces of the inner 
skin $(x=-425 \mathrm{~mm}$ and $x=-575 \mathrm{~mm})$ remained lower than $140^{\circ} \mathrm{C}$ in all cases, thus suggesting that the VF system essentially protects the building façade from direct exposure to the emerging EVF.

\subsection{Assessment of the "Eurocode 1, Part 1-2, Annex B" methodology}

In Eurocode 1, Part 1-2, Annex B [45] a prescriptive methodology to estimate the thermal actions on external members, due to EVF, is provided. It is practically based on the calculation methods proposed by Law [56] and allow the estimation of the maximum temperatures inside the fire compartment, the dimensions and temperature profile of the EVF and the relevant convective and radiative heat fluxes to the external members. This method considers steadystate conditions and is valid only for fire loads higher than $200 \mathrm{MJ} / \mathrm{m}^{2}$. Also, there are specifications regarding the size of the fire compartment; it should not exceed $70 \mathrm{~m}$ in length, $18 \mathrm{~m}$ in width and $5 \mathrm{~m}$ in height. There can be multiple windows and a core within the fire compartment. Since the respective parameters of the performed fire tests were within the aforementioned specifications, the Eurocode methodology was evaluated against the obtained experimental data.

According to the Eurocode methodology, the heat release rate is estimated by using Equation (4). The EVF height, $L_{L}$, is calculated according to Equation (5) in the case there is no forced draught. The EVF horizontal projection, $L_{H}$, in case of a wall existing above the window is given by Equation (6). The EVF flame length, $L_{f}$, and the EVF temperature, $T_{z}$, across the EVF centreline track are given by Equations (7) and (8) respectively. The EVF width is assumed to be equal to the width of the opening. Total horizontal projection, $L_{p}$, corresponds to the sum of the horizontal projection of the flame $\left(L_{H}\right)$ and half the flame depth $\left(2 / 3 h_{e q}\right)$.

$$
\begin{aligned}
& Q=\min \left(\frac{\left(A_{f} \cdot q_{f, d}\right)}{t} ; 3.15\left(1-e^{-0.036 / O}\right) A_{v}\left(\frac{h_{e q}}{D / W}\right)^{1 / 2}\right) \\
& L_{L}=h_{e q}\left[2.37\left(\frac{Q}{\rho_{\infty} A_{v} \sqrt{g h_{e q}}}\right)^{\frac{2}{3}}-1\right] \text {, when } q_{f, d}>200 \mathbf{M J} / \mathbf{m}^{2} \text { and } 0.02 \leq \frac{A_{v} \sqrt{h_{e q}}}{A_{T}} \leq 0.20 \\
& L_{H}=\left\{\begin{array}{c}
\frac{h_{e q}}{3}, \text { when } h_{e q} \leq 1.25 w_{t} \\
0.3 h_{e q}\left(\frac{h_{e q}}{w_{t}}\right)^{0.54}, \text { when } h_{e q}>1.25 w_{t} \text { and } w_{d}>4 w_{t} \\
0.454 h_{e q}\left(\frac{h_{e q}}{2 w_{t}}\right)^{0.54}, \text { in any other case }
\end{array}\right.
\end{aligned}
$$




$$
\begin{aligned}
& L_{f} \\
& =\left\{\begin{array}{c}
L_{L}+\frac{h_{e q}}{2}, \text { if a wall exists above window or if } h_{e q} \leq 1.25 w_{t} \\
\left(L_{L}^{2}+\left(L_{H}-\frac{h_{e q}}{3}\right)^{2}\right)^{1 / 2}+\frac{h_{e q}}{2}, \text { if no wall exists above window or if } h_{e q}>1.25 w_{t}
\end{array}\right.
\end{aligned}
$$

$$
T_{z}=\left(T_{w}-T_{0}\right)\left(1-0.4725\left(\frac{L_{x} \cdot w_{t}}{Q}\right)\right)+T_{0}, \text { with } \frac{L_{x} \cdot w_{t}}{Q}<1
$$

In Table 3, experimental data from both tests are compared to the respective calculations made using the Eurocode methodology (Equations (4)-(8)). In both test cases, the fuel distribution and geometric configuration of the fire compartment were the same and the $h_{e q}>1.25 w_{t}$ condition was valid. The fire load density $\left(q_{f, d}\right)$ was calculated to be $1751 \mathrm{MJ} / \mathrm{m}^{2}$, by assuming a net calorific value of $43.5 \mathrm{MJ} / \mathrm{kg}$ for hexane and complete combustion of $56.7 \mathrm{~kg}$ of hexane. This fire load density corresponds to the largest fire load densities that are used for the fire safety design of library occupancies as recommended in the Eurocode guidelines (EN1991-12, Annex E) [45]. The rate of heat release calculated according to Equation (4) corresponds to 1.14 MW and thus the EVF dimensions can be calculated according to Equations (5) and (6); the EVF width is assumed equal to the width of the opening. The Eurocode methodology is found to significantly under-predict the EVF height, width and centreline temperature in both test cases. Good levels of agreement are observed in the estimation of the maximum projection of the EVF away from the façade. The EVF flame temperature along the EVF axis is estimated using Equation (8) and is compared to the respective time-averaged (over the fully developed fire phase) temperature values measured during the PF and VF test cases in Figure 17. Once more, the Eurocode predictions are found to significantly under-estimate the measured EVF temperatures.

\section{CONCLUSIONS}

Two full-scale compartment-façade fire tests were carried out, aiming to assess the performance of a typical VF system under fire conditions. An extensive set of sensors has been installed both inside and outside the test compartment and across the façade systems, aiming 
to record the temporal variation of several important physical parameters, such as gas and wall surface temperatures, gas velocities, heat flux, EVF envelope shape and fuel mass loss rate. Emphasis has been given on the estimation of the thermal characteristics of the developing EVF, since this is the main physical parameter affecting the heat exposure of the façade systems. A PF and a VF system have been employed; no thermal insulation has been installed in the air cavity of the VF system, aiming to investigate the main aerodynamic and thermal phenomena affecting the flow of hot gases and flames in the air cavity. In addition, no fire barriers have been installed, thus representing a "worst case" scenario for a VF system with no combustible materials. During the initial stages of fire development in both cases, when there is enough oxygen in the compartment, combustion was limited within the interior of the compartment. As soon as the compartment oxygen was depleted, the flames stretched in the horizontal direction, gradually spreading outdoors, forming an EVF. Throughout this latter stage, an oscillating behaviour of the EVF was observed and the EVF volume was highly fluctuating depending on the external wind direction that prevailed in each test case.

Analysis of the experimental data suggested that even though gaseous combustion products have managed to penetrate the air cavity of the VF system, no consistent flaming conditions have been established. More specifically, the temperature values recorded inside the air cavity of the VF system suggested that even though hot combustion products have indeed penetrated into the cavity, there was no consistent flaming. On the unexposed face of the VF system temperatures increased slowly and remained constantly below $180^{\circ} \mathrm{C}$ throughout the entire fire test. It is important to note that these observations are valid for the specific VF configuration tested, where only non-combustible materials were used in conjunction with a relatively small $(25 \mathrm{~mm})$ air cavity width.

The extensive set of experimental data were compared against the Eurocode methodology for EVF calculations, which was found to significantly under-predict the EVF height, width and centreline temperature in both test cases. Good levels of agreement were observed in the case of the maximum projection of the EVF away from the façade. The obtained set of experimental data can be further used to investigate several aspects of EVF fire dynamics and its effect on VF systems under realistic fire loads. They can also be used to validate CFD models or evaluate the accuracy of other fire engineering design correlations currently available. However, further research should be conducted to investigate the applicability of the Eurocode methodology on ventilated façade systems where combustible materials are used. 
The impact of air cavity width in the fire performance of combustible and non-combustible façade systems should also be thoroughly examined.

\section{REFERENCES}

[1] Berardi U, Building energy consumption in US, EU and BRIC countries, Procedia Engineer 2015;118:128-136, https://doi.org/10.1016/j.proeng.2015.08.411

[2] Ibanez-Puy M, Vidaurre-Arbizu M, Sacristan-Fernadez JA, Martin-Gomez C, Opaque Ventilated Facades: Thermal and energy performance review, Renew Sust Energ Rev 2017;79:180-191, https://doi.org/10.1016/j.rser.2017.05.059

[3] Gagliano A, Nocera F, Aneli S, Thermodynamic analysis of ventilated facades under different wind conditions in summer period, Energ Buildings 2016; 122: 131-139, https://doi.org/10.1016/j.enbuild.2016.04.035

[4] Ciampi M, Leccese F, Tuoni G, Ventilated facades energy performance in summer cooling of buildings, Sol Energy 2003; 75: 491-502, https://doi.org/10.1016/j.solener.2003.09.010

[5] Gratia E, De Herde A, Natural cooling strategies efficiency in an office building with a double-skin facade, Energ Buildings 2004; 36: 1139-1152, https://doi.org/10.1016/j.enbuild.2004.05.004

[6] Yu J, Yang J, Xiong C, Study of dynamic thermal performance of hollow block ventilated wall, Renew Energ 2015; 84: 145-151, https://doi.org/10.1016/j.renene.2015.07.020

[7] Tong S, Li H, An efficient model development and experimental study for the heat transfer in naturally ventilated inclined roofs, Build Environ 2014; 81: 296-308, https://doi.org/10.1016/j.buildenv.2014.07.009

[8] Livkiss K, Svensson S, Husted B, van Hees P, Flame heights and heat transfer in facade system ventilation cavities, Fire Technol 2018; 54: 689-719, https://doi.org/10.1007/s10694-018-0706-2

[9] Boström L, Skarin C, Duny M, McNamee R, Fire test of ventilated and unventilated wooden facades, SP Report 2016:16, 2016, Boras.

[10] Bikas D, Tsikaloudaki K, Kontoleon KJ, Giarma C, Tsoka S, Tsigoti D, Ventilated Facades: requirements and specifications across Europe, Procedia Environ Sci 2017; 38: 148-154, https://doi.org/10.1016/j.proenv.2017.03.096 
[11] Jensen G, Fire spread modes and performance of fire stops in vented façade constructions - overview and standardization test methods, MATEC Web of Conferences 2013; 9: 02002p.1-02002 p.11, https://doi.org/10.1051/matecconf/20130902002

[12] Lalu O, Anghel I, Serban M, Mocioi I, Branisteanu B, Experimental researches on determining the fire action response of improved exterior cladding systems provided with incombustible barriers, Energy Procedia 2017; 112: 287-295, https://doi.org/10.1016/j.egypro.2017.03.1099

[13] Giraldo PM, Lacasta A, Avellaneda J, Burgos C, Computer simulation on fire behaviour in the ventilated cavity of ventilated façade systems, MATEC Web of Conferences 2013; 9: 03002, https://doi.org/10.1051/matecconf/20130903002

[14] Nguyen KTQ, Weerasinghe P, Mendis P, Ngo T, Barnett J, Performance of modern building facades in fire: a comprehensive review, Electronic Journal of Structural Engineering 2016; 16: 69-86.

[15] Kolaitis DI, "Safety Aspects of Façade Fires: Novel Risks and Challenges Posed by High Rise Buildings", Chapter 8 in "Novel approaches in Risk, Crisis and Disaster Management", Chalaris M, Emmanouloudis D, Wen JC and Wu ZP (Eds.), Nova Science Publishers Inc., New York; 2018. 305-320 p., ISBN: 978-1-53613-240-3

[16] The Grenfell Tower Inquiry, 2018, https://www.grenfelltowerinquiry.org.uk

[17] Asimakopoulou E, Kolaitis D, Founti M, Thermal characteristics of externally venting flames and their effect on the exposed façade surface, Fire Safety J 2017;91: 451-460, https://doi.org/10.1016/j.firesaf.2017.03.075

[18] Van Hees P, Development of full-scale façade tests in ISO TC92, MATEC Web of Conferences 2016; 46: 01005, https://doi.org/10.1051/matecconf/20164601005

[19] Yokoi S, Study on the prevention of fire spread caused by hot upward current. Building Research Institute, Report No 34 (1960) Tokyo, Japan.

[20] Oleszkiewicz I, Heat transfer from a window fire plume to a building façade. Reprinted from Collected papers in heat transfer, HTD-Vol. 123, Editors: Marner WJ, Chen TC, Faghri M, Peterson GP, Kuehn TH, Pate MB, Mahajan RL and Lavine AS, Book No. H00526, 1989.

[21] Boström L, Hofmann-Böllinghaus A, Colwell S, Chiva R, Toth P, Moder I, Sjöström J, Anderson J, Lange D, Development of a European approach to assess the fire performance of facades, 2018, https://doi.org/10.2873/954759 
[22] Chow WC, Fire safety in green or sustainable buildings: Application of the fire engineering approach in Hong Kong, Archit Sci Rev 2003; 46: 297-303, https://doi.org/10.1080/00038628.2003.9696997

[23] Chow WK, Hung WY, Effect of cavity depth on smoke spreading of double skin façade, Build Environ 2006; 7: 970-979, https://doi.org/10.1016/j.buildenv.2005.04.009

[24] Miao L., Chow CL, A study on window plume from a room fire to the cavity of a doubleskin façade, Appl Therm Eng 2018; 129: 230-241, https://doi.org/10.1016/j.applthermaleng.2017.09.125

[25] Jeffs GMF, Klingelhofer HG, Prager FH, Rosteck H, Fire-Performance of a ventilated façade insulated with a B2-classified rigid polyurethane foam, Fire Mater 1986; 10: 78-89, https://doi.org/10.1002/fam.810100206

[26] White N, Delichatsios M, Fire Hazards of Exterior Wall Assemblies Containing Combustible Components, Springer; 2015, ISBN: 978-1-4939-2898-9

[27] EN 1716, Reaction to fire tests for products - Determination of the gross heat of combustion (calorific value), Brussels, 2018.

[28] Kolaitis D, Asimakopoulou E, Founti M, Fire protection of light and massive timber elements using gypsum plasterboards and wood-based panels: A large-scale compartment fire test, Constr Build Mater 2014; 73: 163-170, https://doi.org/10.1016/j.conbuildmat.2014.09.027

[29] Nakos JT, Uncertainty analysis of thermocouple measurements used in normal and abnormal thermal environment experiments at Sandia's radiant heat facility and Lurance Canyon burn site. Technical Report SAND2004-1023, Sandia National Laboratories, Albuquerque, USA, 2004.

[30] Asimakopoulou E, Chotzoglou K, Kolaitis D, Founti M, Characteristics of Externally Venting Flames and their effect on the façade: a detailed experimental study, Fire Technol 2016; 52: 2043-2069, https://doi.org/10.1007/s10694-016-0575-5

[31] Brohez S, Delvosalle C, Marlair G, A two-thermocouples probe for radiation corrections of measured temperatures in compartment fires, Fire Safety J 2004; 39: 399-411, https://doi.org/10.1016/j.firesaf.2004.03.002

[32] SBG01 Manual v1208, SBG01: Water cooled heat flux sensor according to Schmidt Boelter, 2011.

[33] OMEGA PX277, Differential pressure transducer with field selectable range http://edge.rit.edu/edge/P14414/public/Reference\%20Documents/Hardware\%20Spec\%20 Sheets/PX277.pdf (last accessed: 14 December 2018). 
[34] Sette B, Critical considerations on the use of a bi-directional probe in heat release measurements, Fire Mater 2005; 29: 335-349, https://doi.org/10.1002/fam.886

[35] HBM B2610-1.0, Single point load cells - Data Sheet, Hottinger Baldwin Messtechnik $\mathrm{GmbH}$,

http://www.rcsco.com/products/PDF/HBM/Single\%20Point\%20Load\%20Cells/SP4M.pdf (accessed 09 August 2019).

[36] Thomas IR, Moinuddin KA, Bennetts ID, The effect of quantity and location of fuel on small enclosure fires, J Fire Prot Eng 2017; 17: 85-102, https://doi.org/10.1177/1042391506064908

[37] Hurley M, Gottuk D, Hall J, Harada K, Kuliqowiski E, Puchovsky M, Torero J, Watts J, Wieczorek C, SFPE Handbook of fire protection engineering, $4^{\text {th }}$ Edition, National Fire Protection Association, Quincy, Massachusetts, USA, 2016.

[38] Asimakopoulou E, Kolaitis D, Founti M, Geometrical characteristics of externally venting flames: assessment of fire engineering design correlations using medium scale compartment-façade fire-tests, J Loss Prevent Proc 2016; 44: 780-790, https://doi.org/10.1016/i.jlp.2016.09.006

[39] McCaffrey BJ, Momentum implications for buoyant diffusion flames, Combustion and Flame 1983; 52: 149-156, https://doi.org/10.1016/0010-2180(83)90129-3

[40] Audoin L Kolb G, Torero JL, Most JM, Average centreline temperatures of a buoyant pool fire obtained by image processing of video recordings, Fire Safety J 1995; 24: 167187.

[41] Tang F, Hu LH, Delichatsios MA, Lu KH, Zhu W, Experimental study on flame height and temperature profile of buoyant window spill plume from an under-ventilated compartment fire, International Journal of Heat and Mass Transfer 2012; 55: 93-101, https://doi.org/10.1016/j.ijheatmasstransfer.2011.08.045

[42] Lee Y, Delichatsios MA, Silcock GWH, Heat flux distribution and flame shapes on the inert façade, Fire Safety Science 2008; 9: 193-204, https://doi.org/10.3801/IAFSS.FSS.9$\underline{193}$

[43] Fang X, Ren F, Zhang X, Sun X, Yang Y, Hu L, Façade flame height ejected from opening of a compartment under the coupling effect of side walls and ambient wind, Fire Safety Journal 112 (2020) 102966, https://doi.org/10.1016/j.firesaf.2020.102966

[44] Hu LH, Hu KZ, Ren F, Sun XP, Façade flame height ejected from an opening of fire compartment under external wind, Fire Safety Journal 92 (2017) 151-158, http://dx.doi.org/10.1016/j.firesaf.2017.06.008 
[45] EN 1991-1-2. Eurocode 1, Actions on structures, Part 1-2 - General Actions - Actions on Structures Exposed to Fire, Brussels, 2002.

[46] EN 1364, Fire resistance tests for non-loadbearing elements, Brussels, 2015.

[47] EN 13501-1, Fire classification of construction products and building elements - Part 1: Classification using test data from reaction to fire tests, Brussels, 2019.

[48] ISO 13785-1:2002, Reaction-to-fire tests for facades - Part 1: Intermediate-scale test, International Organization for Standardization, 2002.

[49] ISO 13785-2:2002, Reaction-to-fire tests for facades - Part 12: Intermediate-scale test, International Organization for Standardization, 2002.

[50] DIN E4102-20, Fire behaviour of building materials and building components-Part 20: complementary verification for the assessment of the fire behaviour of external wall claddings, Germany, 2017.

[51] NFPA 285, Standard fire test method for evaluation of fire propagation characteristics of exterior non-load-bearing wall assemblies containing combustible components, National Fire Protection Association, USA, 2012.

[52] BS 8414-1:2015+A1:2017, Fire performance of external cladding systems. Test method for non-loadbearing external cladding systems applied to the masonry face of a building, 2015, British Standards Institution.

[53] BS 8414-2:2015+A1:2017, Fire performance of external cladding systems. Test method for non-loadbearing external cladding systems fixed to and supported by a structural steel frame, 2015, British Standards Institution.

[54] SP FIRE 105, External wall assemblies and façade claddings - Reaction to Fire, Issue 5, Swedish National Testing and Research Institute, 1994.

[55] Clancy P, A parametric study on the time-to-failure of Wood framed walls in fire, Fire Technol 2002; 38: 243-269, https://doi.org/10.1023/A:1019882131985

[56] Manzello LS, Gann GR, Kukuck RS, Lenhert BD, Influence of gypsum board type (X or C) on real fire performance of partition assemblies, Fire Mater 2007; 31: 425-442, https://doi.org/10.1002/fam.940

[56] Law M, "Fire Safety of External Building Elements - The Design Approach", AISC Engineering Journal, 2 ${ }^{\text {nd }}$ Quarter, 1978. 


\begin{tabular}{|c|c|c|}
\hline Symbol & Quantity & Units \\
\hline $\bar{A}$ & Area of the openings of the fire compartment & $\mathrm{m}^{2}$ \\
\hline$A_{v}$ & Total area of vertical openings on all walls & $\mathrm{m}^{2}$ \\
\hline$A_{T}$ & Total area of enclosure (walls, ceiling and floor, including openings) & $\mathrm{m}^{2}$ \\
\hline$D$ & Depth of the fire compartment & $\mathrm{m}$ \\
\hline$g$ & Acceleration of gravity & $9.81 \mathrm{~m} / \mathrm{s}^{2}$ \\
\hline$h_{e q}$ & Weighted average of window heights on all walls & $\mathrm{m}$ \\
\hline$H$ & Height of the opening of the fire compartment & $\mathrm{m}$ \\
\hline$H_{u}$ & Lower heating value & $\mathrm{J} / \mathrm{kg}$ \\
\hline$L_{f, 0.05}$ & Flame height at the "intermittent flame" ( $5 \%$ flame intermittency limit) & $\mathrm{m}$ \\
\hline$L_{f, 0.50}$ & Flame height at the "average flame" (50\% flame intermittency limit) & $\mathrm{m}$ \\
\hline$L_{f, 0.95}$ & Flame height at the "continuous flame" (95\% flame intermittency limit) & $\mathrm{m}$ \\
\hline$L_{H}$ & Horizontal projection of the flame from the facade & $\mathrm{m}$ \\
\hline$L_{L}$ & EVF height & $\mathrm{m}$ \\
\hline$L_{p}$ & Total projection of EVF & $\mathrm{m}$ \\
\hline$L_{x}$ & Length along the EVF centreline track & $\mathrm{m}$ \\
\hline$O$ & Opening factor of the fire compartment & $\mathrm{m}^{1 / 2}$ \\
\hline$Q$ & Rate of heat release of the fire & MW \\
\hline$Q_{E V F}$ & Rate of heat release of the EVF & MW \\
\hline$Q_{\text {total }}$ & Total rate of heat release & MW \\
\hline$Q_{\text {inside }}$ & Rate of heat release of the interior of the fire compartment & MW \\
\hline$q_{f, d}$ & Design fire load density related to the floor area $A_{f}$ & $\mathrm{MJ} / \mathrm{m}^{2}$ \\
\hline$T_{w}$ & Flame temperature at the window & $\mathrm{K}$ \\
\hline$T_{o}$ & Initial temperature $(=293[\mathrm{~K}])$ & $\mathrm{K}$ \\
\hline$t$ & Free burning fire duration (assumed to be $1200[\mathrm{~s}]$ ) & $\mathrm{s}$ \\
\hline$W$ & Width of wall containing window & $\mathrm{m}$ \\
\hline$w_{f}$ & Flame width & $\mathrm{m}$ \\
\hline$\rho_{\infty}$ & Air density & $\mathrm{kg} / \mathrm{m}^{3}$ \\
\hline
\end{tabular}

\section{ABBREVIATIONS}

EVF Externally Venting Flames

HRR Heat Release Rate

MLR Mass Loss Rate 


$$
\begin{array}{ll}
P F & \text { Plain Façade } \\
V F & \text { Ventilated Facade }
\end{array}
$$




\section{TABLE CAPTIONS}

Table 1: Summary of measurement uncertainty components.

Table 2: Summary of the main characteristics of major standard façade tests and current study.

Table 3: Comparison of experimentally determined values of EVF height, width and projection with Eurocode predictions. 


\section{FIGURE CAPTIONS}

Figure 1: General sketch of the Plain Façade PF (left) and the Ventilated Façade VF (right) system.

Figure 2: General schematic drawing of the test rig layout and locations of the horizontal perforated studs on the exposed face of the gypsum plasterboard used in VF test.

Figure 3: Front side (a), support of the façade system (b), perforated metal studs (c) and upper side of the window frame (lintel) (d) for the VF test.

Figure 4: Schematic of the large-scale compartment façade configuration, depicting locations of measurement equipment (left) and a characteristic photo during the fire test (right).

Figure 5: Measurements of fuel mass loss (left) and HRR (right) for the PF and VF tests.

Figure 6: Temporal profiles of gas temperatures at the interior of the compartment at various heights.

Figure 7: Temporal profiles of horizontal velocities at the centreline (mid-span) of the opening at indicated heights below the window lintel for the PF (left) and VF (right) test case.

Figure 8: Front view of flame intermittency contours for the PF (left) and VF (right) test case.

Figure 9: Side view of flame intermittency contours for the PF (left) and VF (right) test case.

Figure 10: Determination of the mean flame height using vertical flame intermittency profile. 
Figure 11: Determination of the mean flame width using horizontal flame intermittency profile.

Figure 12: Determination of the mean flame projection using the flame intermittency profile normal to the façade.

Figure 13: Time-averaged temperature contours at the centreline plane perpendicular to the façade for the PF (left) and VF (right) test case.

Figure 14: Indicative photo of the VF system's air cavity after the test (left), infrared image of the VF system's exposed surface right after flame-out (right).

Figure 15: Temporal evolution of characteristic temperatures across the various layers of the façade systems, at four characteristic heights above the lintel.

Figure 16: Temporal evolution of heat flux at the façade during the PF test, at $500 \mathrm{~mm}(\mathrm{HF} 1)$, $1000 \mathrm{~mm}$ (HF2) and $2000 \mathrm{~mm}$ (HF3) height above the window lintel.

Figure 17: Vertical distribution of measured time-averaged centerline EVF temperatures and comparison to respective predictions using the Eurocode methodology. 